\title{
Analysis of Agricultural Credit Performance of Turkey using K- means Clustering Algorithm
}

\author{
Zeynep Ceylan ${ }^{1 *}$, Selin Sabuncu ${ }^{2}$ \\ ${ }^{1}$ Samsun University, Engineering Faculty, Industrial Engineering, Samsun, Turkey (ORCID: 0000-0002-3006-9768) \\ ${ }^{2}$ Ondokuz Mayıs University, Engineering Faculty, Industrial Engineering, Samsun, Turkey (ORCID: 0000-0001-9144-1642)
}

(Bu yayın International Congress on Human-Computer Interaction,Optimization and Robotic Application kongresinde sözlü olarak sunulmuştur.)

(First received 1 August 2019 and in final form 25 October 2019)

(DOI: 10.31590/ejosat.638434)

ATIF/REFERENCE: Ceylan, Z. \& Sabuncu, S. (2019). Analysis of Agricultural Credit Performance of Turkey using K-means Clustering Algorithm. European Journal of Science and Technology, (Special Issue), 478-484.

\begin{abstract}
Agriculture is a significant sector that supplies raw materials to many sectors as well as providing nutrients to humans and animals and ensures employment. The economic crises, rapid population growth, the rise in demand for food products have increased importance and necessity of agriculture. For this reason, agriculture must be supported in order not to be affected by adverse conditions and effects. Thus, agricultural credit is an important factor in the development of the production and investment structure of the agricultural sector. In this study, agricultural credit performance of 81 provinces in Turkey in 2018 was compared by taking into consideration the value of total agricultural production, total cultivated area and the amount of agricultural credit used. The data used in this study were collected from the Banking Regulation and Supervision Agency (BRSA) and the Turkish Statistical Institute. In order to determine relationships between the 81 provinces of Turkey, one of the nonhierarchical clustering method, i.e. the K-means clustering method was applied using SPSS Clementine data mining software. As a result, the credit performance of provinces was evaluated and similarities and differences were revealed using agricultural production value, total cultivated land, agricultural credit volume data.
\end{abstract}

Keywords: Agricultural credit performance, Clustering, K-means, Data mining

\section{Türkiye'nin Tarımsal Kredi Performansının K-ortalamalar Kümeleme Algoritması ile Analizi}

$\ddot{O} \mathbf{z}$

Tarım, insanlara ve hayvanlara besin sağlamanın yanısıra birçok sektöre hammadde ve istihdam sağlayan önemli bir sektördür. Ekonomik krizler, hızlı nüfus artışı, gıda ürünlerine olan talebin artması, tarımın önemini ve gerekliliğini arttırmıştır. Bu nedenle, olumsuz koşullardan ve etkilerden etkilenmemesi için tarım desteklenmelidir. Dolayısıyla, tarımsal kredi, tarım sektörünün üretim ve yatırım yapısının gelişiminde önemli bir faktördür.

Bu çalışmada, 2018 yılında Türkiye'deki 81 ilin tarımsal kredi performansı, toplam tarımsal üretim değeri, toplam ekili alan ve kullanılan tarımsal kredi miktarı dikkate alınarak karşılaştırılmıştır. Bu çalışmada kullanılan veriler Bankacılık Düzenleme ve Denetleme Kurumu'ndan (BDDK) ve Türkiye İstatistik Kurumu'ndan toplanmıştır. Türkiye'nin 81 ili arasındaki ilişkileri belirlemek için, hiyerarşik olmayan kümeleme yöntemlerinden biri olan K-ortalamalar kümeleme yöntemi, SPSS Clementine veri madenciliği yazılımı kullanılarak uygulanmıştır. Sonuç olarak, tarımsal üretim değeri, toplam ekili alan, tarımsal kredi hacmi verileri kullanılarak illerin kredi performansı değerlendirilmiş ve benzerlikler ve farklılıklar ortaya konulmuştur.

\footnotetext{
${ }^{*}$ Corresponding Author: Samsun University, Engineering Faculty, Industrial Engineering, Samsun, Turkey, ORCID: 0000-0002-3006-9768, zeynep.ceylan@samsun.edu.tr
} 
Anahtar Kelimeler: Tarımsal kredi performansı, Kümeleme, K-ortalamalar, Veri madenciliği

\section{Introduction}

Agriculture is a crucial sector for Turkey in terms of social and economic aspects. The importance of agriculture in the economy of Turkey and other countries is measured as the added-value of the agricultural sector as percent of Gross Domestic Product (GDP). After the 1980s, the share of agriculture in GDP has declined in Turkey as a result of greater emphasis on industrialization, the reduction of the state's tendency for agricultural protection with the laws, and customizations processes. While the contribution of agriculture to GDP was $\% 17,7$ in 1987, it has dropped to \%6,1 (52,3 billion dollars) in 2016. As shown Fig. 1, with the economic development, the share of the industry and services sector in the economy increases while the share of the agricultural sector in the economy is gradually decreasing.

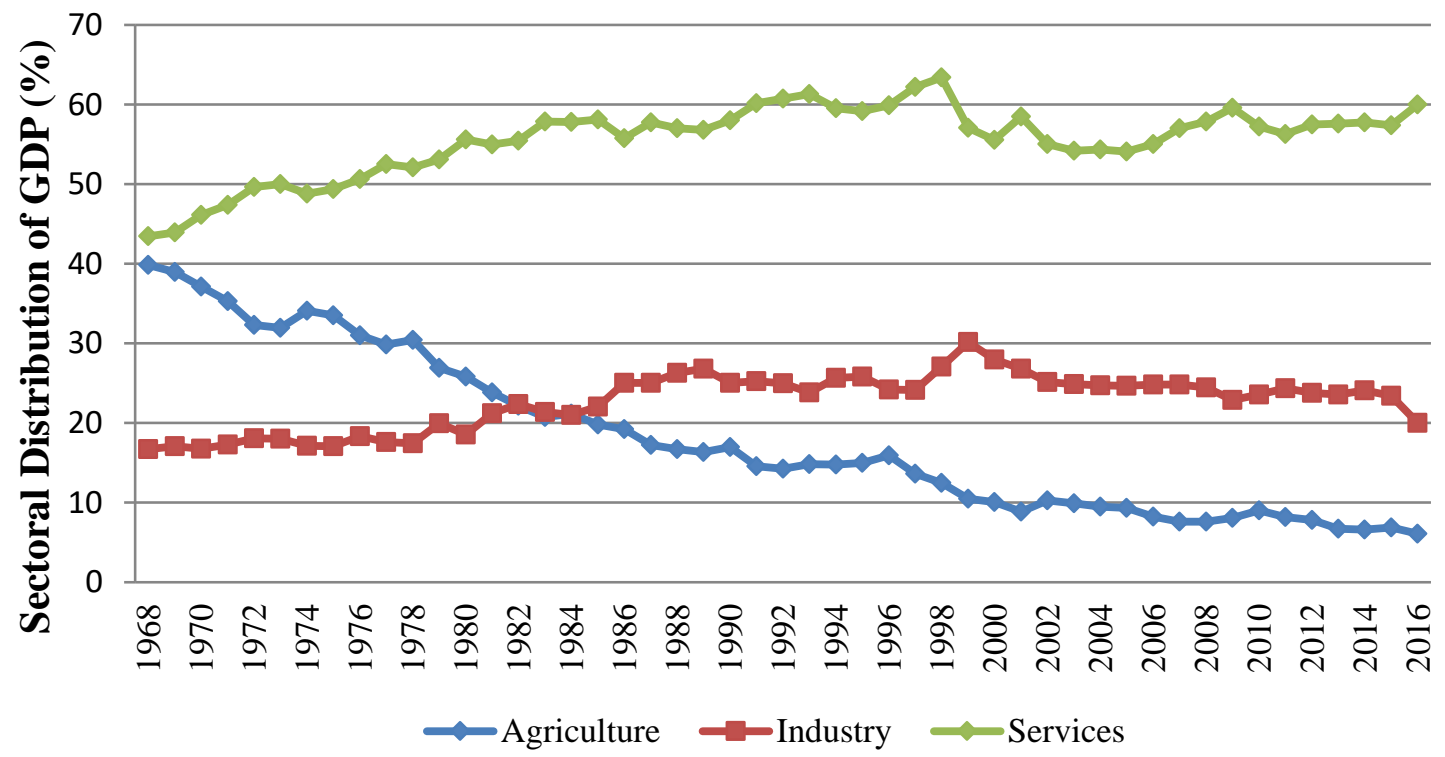

Figure 1. Sectoral Distribution of GDP between 1968-2016

One of the most important factors for the sustainability of production in agriculture is financing (Terin et al., 2014; Adanacioğlu et al., 2017, Chandio et al., 2017). Because, the credit and input support provided to the agricultural sector directly affects agricultural production. Agricultural credit allows farmers to access new technologies and take advantage of new economic opportunities to increase production and income (e Saqib et al., 2016). For this reason, it must be supported to create a sustainable, competitive and organized agricultural sector (Hayran and Gül, 2018).

Agricultural credit usage in Turkey has experienced a rapid decline between 1997 and 2002. As shown Figure, the use of agricultural credits, which increased to 42.1 billion TL in 1997, declined to 6.6 billion TL in 2002. However, after 2002, the use of agricultural credits started to increase with the improvement of the credit utilization conditions and the provision of credit to the agricultural sector of private banks. The use of agricultural credit, which was 6.5 billion TL in 2002, has increased to 24.8 billion TL in 2012. The agriculture received about 3.3\% (68.239 Thousand TL) of total credit used in Turkey, 2017. This can be explained by the fact that agricultural producers receive lower amounts of credit from producers in other sectors.

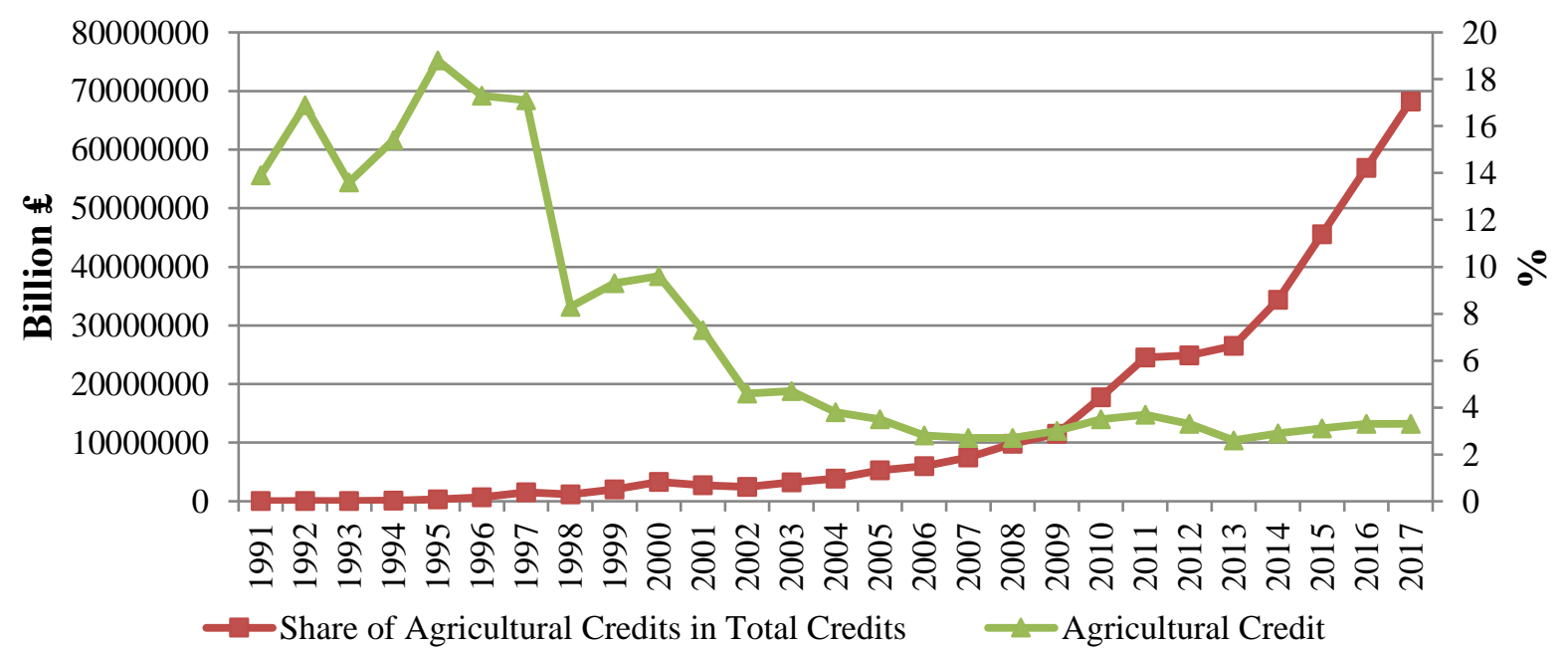

Figure 2. Agricultural Credit Usage in Turkey and Share in Total Loans (\%) 
In this study, agricultural credit performance of Turkey in 2018 was analzed. The 81 provinces of Turkey were taken as objects of research and they were described by three attributes (variables), i.e. the total agricultural production value, total agricultural credit volume and total cultivated land. In the analysis, k-means clustering method, which is one of the non-hierarchical cluster analysis methods, was used. The objective of the analysis is to group the provinces into clusters (subgroups) that are most similar to each other in the same cluster and most unlike in other clusters. The analyses were carried out based on reports and statistics of The Banks Association of Turkey and Banking Regulation and Supervision Agency (BRSA) and Turkish Statistical Institute (TURKSTAT).

\section{Material and Method}

\subsection{Dataset}

The agricultural credit performance of 81 provinces of Turkey in the year 2018 was analyzed according to based on the total agricultural production value (crop and animal production, and live animals values), total cultivated land, and total credit volume variables. Then, per capita values for all variables were obtained by dividing each province by the number of population in 2018 . As shown in Table 1, the data were collected from different data sources. The used dataset for the analysis was presented in Table 2.

Table 1. Definition of the Variables

\begin{tabular}{llll}
\hline Variable & Definition & Unit of Measurement & Data Source \\
\hline APV & Agricultural Production Value & Thousand $€(T L)$ & Turkstat $^{*}$ \\
TCL & Total Cultivated Land & Hectare & Turkstat $^{*}$ \\
TCV & Total Credit Volume & Thousand $€$ & BRSA $^{* *}$ \\
POP & Population size & Million & Turkstat \\
\hline \multicolumn{2}{c}{ * Turkish Statistical Institute, } & & \\
&
\end{tabular}

\subsection{Data Mining}

Today, rapid development in data collection and storage technology allows organizations to accumulate large amounts of data. However, it is difficult to extract useful information from these data. Traditional data analysis tools and techniques are insufficient to analyze such a large data set. At this point, data mining fills a significant gap. Data mining is a technology that blends algorithms developed to analyze large volumes of data (Kamber and Pei, 2006). Chen et al. (2006) defined data mining as the process of extracting information or patterns from interesting (non-trivial, confidential, previously unknown and potentially useful) information in large database.

\subsection{Clustering Analysis}

Clustering analysis is one of the important descriptive models used in data mining. Clustering analysis is a statistical technique used in many fields; including image processing, market research, information retrieval, bioinformatics, machine learning, pattern recognition, computer graphics and etc. The main task of cluster analysis is to identify subgroups in the data such that data points in the same subgroup (cluster) are very similar while data points in different clusters are very different.

Several clustering algorithms have been proposed in data mining. In the literature, these algorithms are generally classified as hierarchical and non-hierarchical. In the hierarchical clustering algorithm, two methods are used: agglomerative and divisive. In the agglomerative method, each object is initially considered as a seperate cluster (leaf). Then, the two closest (most similar) clusters are then merged into a new cluster. The process repeats until all data points (clusters) will be merged into the same cluster. In this way, the number of clusters is reduced one step at a time. The resulting cluster structure can be represented by "dendrogram" or tree graph. The most popular algorithms are median method, single linkage, furthest neighbor (complete linkage), centroid method or Ward's method. Each of these algorithms can give different results. On the other hand, the process of the divisive method is the inverse of the agglomerative method. Initially, all the observations are proceed as a single cluster, then the following divisions continue until $\mathrm{n}$ clusters are obtained. The main drawback of hierarchical methods is that it is difficult to decide the appropriate cluster number, although there are some suggestions for solving the problem.

\subsection{K-Means Method}

K-means clustering is one of the most popular and effective non-hierarchical method. The goal of this algorithm is to partition $\mathrm{n}$ observations into k clusters. Algorithm is strongly dependent on the value of $\mathrm{k}$. The algorithm runs in iterative (repetitive) steps to define each data point to one of $\mathrm{k}$ groups dependin on the provided features. Data points are clustered according to feature similarity.

In K-means method, determining the best number of clusters is a fundamental problem. Because it has a deterministic effect on the clustering results. The amount of clusters must be large enough to represent certain characteristics of the data set. Additionally, the value of $\mathrm{k}$ must be less than the number of objects in the data set. In most studies, there are suggestions for determining the appropriate values of k. (Pham et al., 2005). 
European Journal of Science and Technology

Table 2. APV, TCV, TCL, and Population Values in the 81 Provinces of Turkey (2018)

\begin{tabular}{|c|c|c|c|c|c|}
\hline Region Code & Province & APV (1000 छ) & TCV (1000 छ) & TCL (HA) & Population \\
\hline TR621 & Adana & 9755979 & 4277357 & 411894 & 2220125 \\
\hline TRC12 & Adiyaman & 3151019 & 641200 & 175902 & 624513 \\
\hline TR332 & Afyonkarahisar & 6839585 & 1587937 & 447391 & 725568 \\
\hline TRA21 & Agri & 4022055 & 340480 & 353496 & 539657 \\
\hline TR712 & Aksaray & 4821250 & 946096 & 387423 & 412172 \\
\hline TR834 & Amasya & 3695394 & 737720 & 220755 & 337508 \\
\hline TR510 & Ankara & 9637745 & 8813872 & 1159710 & 5503985 \\
\hline TR611 & Antalya & 13401717 & 4254141 & 283203 & 2426356 \\
\hline TRA24 & Ardahan & 2248035 & 526200 & 38890 & 98907 \\
\hline TR905 & Artvin & 1389716 & 172300 & 10615 & 174010 \\
\hline TR321 & Aydin & 7287372 & 2894304 & 141096 & 1097746 \\
\hline TR221 & Balikesir & 8544157 & 2332854 & 298808 & 1226575 \\
\hline TR813 & Bartin & 701590 & 85804 & 31441 & 198999 \\
\hline TRC32 & Batman & 2094114 & 256641 & 81809 & 599103 \\
\hline TRA13 & Bayburt & 859069 & 193465 & 97069 & 82274 \\
\hline TR413 & Bilecik & 1155918 & 247227 & 68472 & 223448 \\
\hline TRB13 & Bingöl & 1679897 & 177925 & 26978 & 281205 \\
\hline TRB23 & Bitlis & 1876283 & 342060 & 119039 & 349396 \\
\hline TR424 & Bolu & 1625705 & 574052 & 110256 & 311810 \\
\hline TR613 & Burdur & 3570574 & 728776 & 140425 & 269926 \\
\hline TR411 & Bursa & 8473551 & 2758012 & 211661 & 2994521 \\
\hline TR222 & Çanakkale & 6032687 & 1174191 & 234642 & 540662 \\
\hline TR822 & Çankiri & 1729994 & 563953 & 201763 & 216362 \\
\hline TR833 & Çorum & 4034563 & 964320 & 512695 & 536483 \\
\hline TR322 & Denizli & 6614214 & 1873065 & 271414 & 1027782 \\
\hline TRC22 & Diyarbakir & 8817611 & 1521821 & 547715 & 1732396 \\
\hline TR423 & Düzce & 1151384 & 429072 & 11106 & 387844 \\
\hline TR212 & Edirne & 3745960 & 1396325 & 310021 & 411528 \\
\hline TRB12 & Elazig & 3328820 & 541174 & 158594 & 595638 \\
\hline TRA12 & Erzincan & 2001092 & 432816 & 122103 & 236034 \\
\hline TRA11 & Erzurum & 6439752 & 1126376 & 337992 & 767848 \\
\hline TR412 & Eskisehir & 3811756 & 1089750 & 537266 & 871187 \\
\hline TRC11 & Gaziantep & 7286341 & 2281402 & 135181 & 2028563 \\
\hline TR903 & Giresun & 1837296 & 418920 & 37053 & 453912 \\
\hline TR906 & Gümüshane & 947586 & 201193 & 81001 & 162748 \\
\hline TRB24 & Hakkâri & 1137413 & 111532 & 36348 & 286470 \\
\hline TR631 & Hatay & 4766449 & 1441802 & 138073 & 1609856 \\
\hline TRA23 & Igdir & 2460457 & 399937 & 97033 & 197456 \\
\hline TR612 & Isparta & 3709553 & 738758 & 161453 & 441412 \\
\hline TR100 & İstanbul & 1695212 & 4457995 & 69613 & 15067724 \\
\hline TR310 & İzmir & 13761983 & 6135855 & 176069 & 4320519 \\
\hline TR632 & Kahramanmaraş & 4857753 & 975539 & 301698 & 1144851 \\
\hline TR812 & Karabük & 415729 & 104228 & 33385 & 248014 \\
\hline TR522 & Karaman & 4415707 & 630791 & 298756 & 251913 \\
\hline TRA22 & Kars & 4278282 & 732509 & 207446 & 288878 \\
\hline TR821 & Kastamonu & 2984027 & 649898 & 127034 & 383373 \\
\hline TR721 & Kayseri & 5688490 & 1746937 & 558247 & 1389680 \\
\hline TRC13 & Kilis & 910854 & 189657 & 48105 & 142541 \\
\hline TR711 & Kirikkale & 1462183 & 406306 & 298777 & 286602 \\
\hline TR213 & Kirklareli & 2810644 & 1156418 & 234323 & 360860 \\
\hline TR715 & Kirsehir & 3432697 & 1104002 & 347344 & 241868 \\
\hline TR421 & Kocaeli & 1547442 & 651443 & 66148 & 1906391 \\
\hline TR521 & Konya & 19374921 & 4984523 & 1837344 & 2205609 \\
\hline TR333 & Kütahya & 3136613 & 588125 & 306707 & 577941 \\
\hline TRB11 & Malatya & 3478114 & 1001356 & 187408 & 797036 \\
\hline TR331 & Manisa & 8212299 & 3383677 & 284905 & 1429643 \\
\hline TRC31 & Mardin & 3618128 & 699356 & 271442 & 829195 \\
\hline TR622 & Mersin & 10952655 & 2842088 & 200233 & 1814468 \\
\hline TR323 & Muğla & 5756231 & 2742734 & 109626 & 967487 \\
\hline TRB22 & Muş & 3781157 & 406052 & 241553 & 407992 \\
\hline TR714 & Nevşehir & 2230745 & 565501 & 304199 & 298339 \\
\hline TR713 & Niğde & 5002262 & 842356 & 239623 & 364707 \\
\hline TR902 & Ordu & 3775260 & 785745 & 25053 & 771932 \\
\hline TR633 & Osmaniye & 2132862 & 507654 & 103220 & 534415 \\
\hline TR904 & Rize & 2817733 & 371979 & 542 & 348608 \\
\hline TR422 & Sakarya & 3211528 & 1067573 & 78850 & 1010700 \\
\hline TR831 & Samsun & 5605900 & 1396633 & 257561 & 1335716 \\
\hline TRC 21 & Şanlıurfa & 12335460 & 2225012 & 896645 & 2035809 \\
\hline TRC34 & Siirt & 1995328 & 197831 & 57665 & 331670 \\
\hline TR823 & Sinop & 1039672 & 223205 & 73743 & 219733 \\
\hline TRC33 & Şırnak & 1482552 & 115836 & 102052 & 524190 \\
\hline TR722 & Sivas & 5041851 & 1243149 & 775370 & 646608 \\
\hline TR211 & Tekirdağ & 3696738 & 1646096 & 385528 & 1029927 \\
\hline TR832 & Tokat & 4983248 & 816339 & 289562 & 612646 \\
\hline TR901 & Trabzon & 2537680 & 470222 & 14356 & 807903 \\
\hline TRB14 & Tunceli & 674203 & 158134 & 48451 & 88198 \\
\hline TR334 & Uşak & 2466370 & 547667 & 206183 & 367514 \\
\hline TRB21 & Van & 4116608 & 564375 & 284239 & 1123784 \\
\hline TR425 & Yalova & 396541 & 192574 & 5893 & 262234 \\
\hline TR723 & Yozgat & 4104498 & 1223651 & 609314 & 424981 \\
\hline TR811 & Zonguldak & 1082309 & 163438 & 25561 & 599698 \\
\hline
\end{tabular}




\section{Results ant Discussion}

\subsection{Determining Number of Clusters}

In order to ensure comparability between the collected data, normalization standardization method was applied by following Eq. 1 (Nisbet et al., 2009).

$$
z_{i}=\frac{x_{i-\bar{x}}}{S_{x}}
$$

where x and $S_{x}$ are mean and standard deviation of the used variable in the data, respectively. Using SPSS Clementine software the groupings of provinces was performed with K-means clustering algorithm. In this method, the number of clusters must be determined before starting the clustering analysis. In order to evaluate the $\mathrm{k}$ values in the analysis, the preliminary computations were made by agglomerative method (Herbin et al., 2001). Some confirmation of appropriateness of such a number of clusters is the use of a rule of thumb, $\mathrm{k} \cong \sqrt{n / 2}$, whereby $\mathrm{k} \cong \sqrt{81 / 2}$ (Kijewska and Bluszcz, 2016). Same calculations were performed with the $\mathrm{k}$-means method to confirm this value, assuming $\mathrm{k}=2,3,4,5$ and 6 . Table 3 shows the values for the sum of squares error (SSE) for each number of clusters. As a result, the number of cluster with the minimum SSE was specified as 5.

Table 3. Number of Clusters and Sum of Squares Error for K-means Method

\begin{tabular}{llllll}
\hline Number of Cluster & $\mathbf{K = 2}$ & $\mathbf{K = 3}$ & $\mathbf{K = 4}$ & $\mathbf{K = 5}$ & $\mathbf{K = 6}$ \\
\hline SSE & 0.596 & 0.663 & 0.755 & 0.318 & 0.321 \\
\hline
\end{tabular}

\subsection{Clustering by K-means Method}

Clustering of provinces in terms of per capita TPV, TCL and TCV shows significant differences in the obtained clusters. Cluster no. 1 comprises of 48 provinces (including İstanbul, İzmir, Ankara and etc), cluster no. 2 and cluster no. 3 have only one province (Kırşehir and Ardahan, respectively), the fourth cluster contains 11 provinces and the fifth cluster consists of 20 provinces. The obtained clusters and corresponding distances from the cluster centers are presented in Table 4.

Table 4. Obtained Clusters with Distances from Centers

\begin{tabular}{|c|c|c|c|c|c|c|c|c|c|c|c|}
\hline \multicolumn{4}{|c|}{ Cluster 1} & \multicolumn{2}{|c|}{ Cluster 2} & \multicolumn{2}{|c|}{ Cluster 3} & \multicolumn{2}{|c|}{ Cluster 4} & \multicolumn{2}{|c|}{ Cluster 5} \\
\hline Province & Distance & Province & Distance & Province & Distance & Province & Distance & Province & Distance & Province & Distance \\
\hline Adana & 0.162 & Kahramanmaraş & 0.078 & Kırşehir & 0.000 & Ardahan & 0.000 & Aksaray & 0.125 & Afyonkarahisar & 0.095 \\
\hline Adiyaman & 0.080 & Karabük & 0.181 & & & & & Bayburt & 0.107 & Ağr1 & 0.250 \\
\hline Ankara & 0.153 & Kayseri & 0.160 & & & & & Çankırı & 0.115 & Amasya & 0.138 \\
\hline Antalya & 0.144 & Kilis & 0.151 & & & & & Çorum & 0.142 & Burdur & 0.257 \\
\hline Artvin & 0.181 & Kocaeli & 0.238 & & & & & Edirne & 0.295 & Çanakkale & 0.142 \\
\hline Aydin & 0.320 & Malatya & 0.051 & & & & & Karaman & 0.376 & Erzincan & 0.033 \\
\hline Balıkesir & 0.201 & Manisa & 0.257 & & & & & Kırıkkale & 0.256 & Erzurum & 0.100 \\
\hline Bartın & 0.137 & Mardin & 0.116 & & & & & Konya & 0.149 & Eskişehir & 0.238 \\
\hline Batman & 0.140 & Mersin & 0.127 & & & & & Nevşehir & 0.117 & Gümüşhane & 0.183 \\
\hline Bilecik & 0.097 & Muğla & 0.350 & & & & & Sivas & 0.149 & Iğdır & 0.161 \\
\hline Bingöl & 0.129 & Ordu & 0.104 & & & & & Yozgat & 0.295 & Isparta & 0.129 \\
\hline Bitlis & 0.125 & Osmaniye & 0.035 & & & & & & & Kars & 0.317 \\
\hline Bolu & 0.194 & Rize & 0.205 & & & & & & & Kastamonu & 0.159 \\
\hline Bursa & 0.106 & Sakarya & 0.087 & & & & & & & Kırklareli & 0.293 \\
\hline Denizli & 0.180 & Samsun & 0.017 & & & & & & & Kütahya & 0.221 \\
\hline Diyarbakır & 0.111 & Şanliurfa & 0.199 & & & & & & & Muş & 0.159 \\
\hline Düzce & 0.120 & Siirt & 0.123 & & & & & & & Niğde & 0.243 \\
\hline Elâzığ & 0.091 & Sinop & 0.113 & & & & & & & Tokat & 0.110 \\
\hline Gaziantep & 0.084 & Şırnak & 0.185 & & & & & & & Tunceli & 0.063 \\
\hline Giresun & 0.076 & Tekirdağ & 0.172 & & & & & & & Uşak & 0.120 \\
\hline Hakkâri & 0.145 & Trabzon & 0.160 & & & & & & & & \\
\hline Hatay & 0.097 & Van & 0.132 & & & & & & & & \\
\hline İstanbul & 0.273 & Yalova & 0.180 & & & & & & & & \\
\hline İzmir & 0.125 & Zonguldak & 0.219 & & & & & & & & \\
\hline
\end{tabular}

The clusters obtained by the K-means method and the effects of variables on clusters are shown in Fig. 3. In the SPSS Clementine, it is accepted that the effects of variables with significance levels below 0.90 on clusters are not significant. As can be seen in Fig. 3 , it can be concluded that the effects of all variables on the three clusters are significant. 


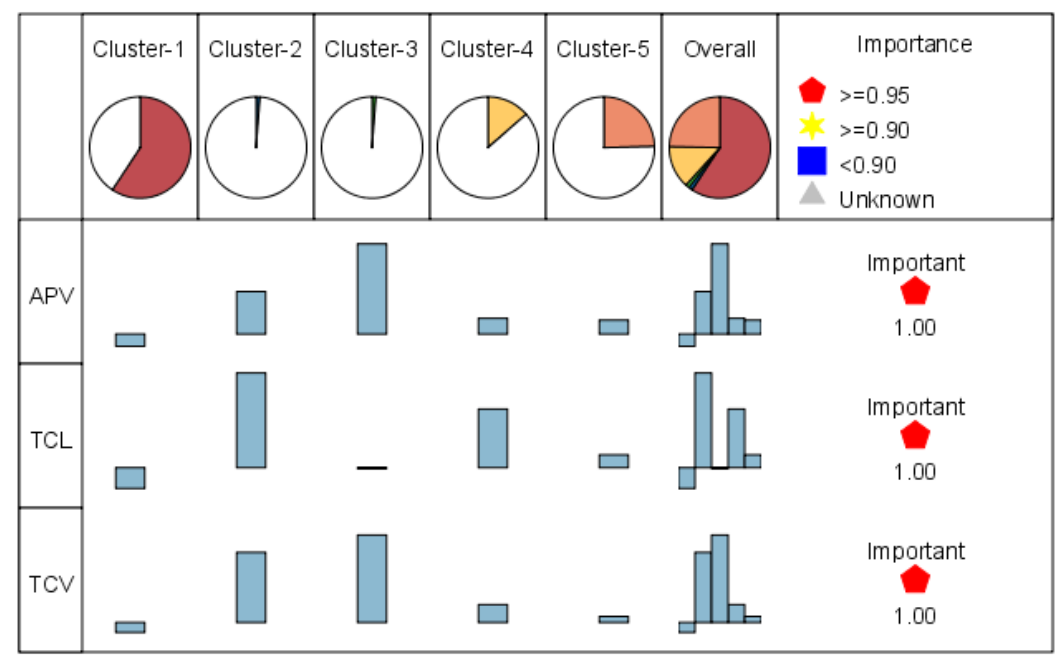

Figure 3. The Clusters Obtained by K-Means Method

\subsection{Statistical Analysis}

Table 5 shows the average values of used variables per capita in each cluster. Table 6 represents descriptive statistics of clusters on the basis of standardized data for all variables.

Table 5. The Average Values of Variables in Clusters (per Capita)

\begin{tabular}{llll}
\hline Cluster No. & APV & TCV & TCL \\
\hline Cluster 1 & 4.358 & 1.099 & 0.177 \\
Cluster 2 & 14.192 & 4.564 & 1.436 \\
Cluster 3 & 22.728 & 5.320 & 0.393 \\
Cluster 4 & 9.373 & 2.302 & 1.043 \\
Cluster 5 & 9.071 & 1.787 & 0.544 \\
\hline
\end{tabular}

It is seen that 48 provinces creating the first cluster is characterized by the lowest values of average agricultural production value. On the other hand, cluster 2 and cluster 3 have the highest average agricultural production value and total cultivated land. In this case, it can be concluded that the smaller the number of clusters, the higher the average values of agricultural production and cultivated land.

Table 6. Descriptive Statistics of Clusters on the Basis of Standardized Data for Used Variables

\begin{tabular}{lrrr}
\hline Cluster No. & Means & $\begin{array}{c}\text { Standart } \\
\text { Deviation }\end{array}$ & Variance \\
\hline Cluster 1 (48 records) & & & \\
\hline$A P V$ & -0.57 & 0.46 & 0.21 \\
TCL & -0.65 & 0.35 & 0.12 \\
TCV & -0.46 & 0.65 & 0.42 \\
\hline Cluster 2 (1 record) & & & \\
\hline APV & 2.00 & 0.00 & 0.00 \\
TCL & 2.97 & 0.00 & 0.00 \\
TCV & 3.29 & 0.00 & 0.00 \\
\hline Cluster 3 (1 record) & & & \\
\hline APV & 4.24 & 0.00 & 0.00 \\
TCL & -0.03 & 0.00 & 0.00 \\
TCV & 4.11 & 0.00 & 0.00 \\
\hline Cluster 4 (11 records) & & & \\
\hline APV & 0.74 & 0.84 & 0.71 \\
TCL & 1.84 & 0.56 & 0.31 \\
TCV & 0.84 & 0.59 & 0.35 \\
\hline Cluster 5 (20 records) & & & \\
\hline APV & 0.66 & 0.74 & 0.55 \\
TCL & 0.40 & 0.30 & 0.09 \\
TCV & 0.28 & 0.69 & 0.48 \\
\hline
\end{tabular}




\section{Conclusions}

The increase in agricultural production, which is one of the basic elements of economic development, depends on the purposeoriented investments, application of technological innovations and continuous production with increased productivity. One of the most important factors for the continuity of production in agriculture is financing. Agricultural credit is an important factor in the development of the production and investment structure of the agricultural sector in both developed and developing countries and is an important tool of agricultural development. Thus, effective utilization of loans has been one of the main objectives in achieving agricultural development in all development plans and programs.

In this study, the 81 provinces of Turkey in 2018 were divided into clusters using the per capita agricultural production value, agricultural credit volume, and total cultivated area data. For the analysis, the k-means clustering method, which is the most common exploratory data analysis technique was used in data mining. In the first step, in order to determine the number of clusters, additional calculations and normalization standardization method were applied to the dataset. Then, in terms of sum square error value, $\mathrm{k}$ was determined as equal 5: cluster 1 consists of 48 provinces, cluster 2 and cluster 3 has consist of 1 province, cluster 4 contains 11 provinces, and cluster 5 includes 20 provinces. On the basis of the statistics, it was concluded that the effects of all variables on the three clusters are significant. As a result, clustering of provinces in terms of APV, TCL, and TCV per capita shows that there are significant differences in obtained clusters.

\section{References}

Adanacıŏglu, H., Artukoğlu, M., \& Güneş, E. (2017). Türkiye'de Tarımsal Kredi Performansının Çok Boyutlu Ölçekleme Yaklaşımıyla Analizi. Turkish Journal of Agricultural Economics, 23(2).

Chandio, A. A., Jiang, Y., Gessesse, A. T., \& Dunya, R. (2017). The nexus of agricultural credit, farm size and technical efficiency in Sindh, Pakistan: A stochastic production frontier approach. Journal of the Saudi Society of Agricultural Sciences.

Chen, Y. L., Chen, J. M., \& Tung, C. W. (2006). A data mining approach for retail knowledge discovery with consideration of the effect of shelf-space adjacency on sales. Decision support systems, 42(3), 1503-1520.

e Saqib, S., Ahmad, M. M., Panezai, S., \& Ali, U. (2016). Factors influencing farmers' adoption of agricultural credit as a risk management strategy: The case of Pakistan. International journal of disaster risk reduction, 17, 67-76.

Hayran, S., \& Gül, A. (2018). Mersin İlinde Çiftçilerin Tarımsal Kredi Kullanım Kararlarını Etkileyen Faktörler. Iğdır Üniversitesi Fen Bilimleri Enstitüsü Dergisi, 8(1), 271-277.

Herbin, M., Bonnet, N., \& Vautrot, P. (2001). Estimation of the number of clusters and influence zones. Pattern Recognition Letters, 22(14), 1557-1568.

Kamber, M., \& Pei, J. (2006). Data Mining. Morgan kaufmann.

Kijewska, A., \& Bluszcz, A. (2016). Research of varying levels of greenhouse gas emissions in European countries using the k-means method. Atmospheric Pollution Research, 7(5), 935-944.

Nisbet, R., Elder, J., \& Miner, G. (2009). Handbook of statistical analysis and data mining applications. Academic Press.

Pham, D. T., Dimov, S. S., \& Nguyen, C. D. (2005). Selection of K in K-means clustering. Proceedings of the Institution of Mechanical Engineers, Part C: Journal of Mechanical Engineering Science, 219(1), 103-119.

Terin, M., Güler, İ. O., \& Aksoy, A. (2014). Türkiye'de tarımsal üretim ile tarımsal kredi kullanımı arasındaki nedensellik ilişkisi. Iğdır Üniversitesi Fen Bilimleri Enstitüsü Dergisi, 4(1), 67-72. 